\title{
How honey bees forage for pollen at skunk cabbage, Symplocarpus fotidus (Araceae)
}

\author{
P.G. Kevan
}

University of Guelph, Department of Environmental Biology, Guelph, Ontario N1G 2W1, Canada

(received 26 May 1989, accepted 23 June 1989)

\begin{abstract}
Summary - Skunk cabbages flower in early spring, often through snow, ice and frozen ground in swampy woodlands in Northeastern North America. The nectarless inflorescences produce heat and mimetic scents, notably carrion, apple, turnip and garlic; however they are sometimes unscented. They are protogynous and, in the male phase, produce pollen copiously. Pollen collecting honeybees do not visit unscented spathes, instead they visit scented ones depending on the proportion of the various scents in a given foraging patch. They visit polleniferous inflorescences more often than predicted, purely by chance. No relationship has been established between the presence of pollen and scent. Polleniferous inflorescences have yellowish or yellow-spotted spadices; older spadices and immature ones are dark. Honeybees appeared to orient first by scent, and then by vision, in choosing inflorescences. They foraged in patches with more polleniferous spathes than other patches, where they were not seen. Thus, honey bees concentrated their foraging on resource-rich, scented spathes within resource-rich patches.
\end{abstract}

Apis mellifera - foraging behaviour - pollen - Symplocarpus foetidus - North America

\section{INTRODUCTION}

Bees forage on a variety of flowers to obtain pollen. Little has been written on the foraging pattern of apid bees gathering pollen, despite the wealth of information on their foraging for nectar (Pyke, 1978 a, b; Waddington, 1983). Most of research that has been carried out on bumblebees (Bombus) (Haynes \& Mesler, 1984, working with Lupinus polyphyllus Lindl. (Leguminosae) and Galen \& Plowright, 1985, working with Epilobium augustifolium L. (Onagraceae)), documented that Bombus spp. (Hymenoptera : Apidae) foraged for pollen on inflorescences by starting low and working upwards, as predicted by the principles of optimality (Pyke, 1978a, b, 1979). Zimmerman (1982a) compared the differences in inter-inflorescence movements between nectar- and pollen- collecting Bombus spp. He observed that they made shorter flights between inflorescence when they were foraging for pollen on $L$. amplus Greene, than when they were foraging for nectar from Thermopsis divaricarpa $A$. 
Nels. (Leguminosae). Zimmerman (1982b) further observed that Bombus spp. foraging for pollen at Potentilla gracilis Dougl. (Rosaceae) moved randomly with regard to direction, and sequential visits tended to be to the nearest neighbours. Hodges and Miller (1981) followed Bombus spp. as they foraged for pollen from Aquilegia caerulea James (Ranunculaceae) and noticed that they tended not to move backwards, but that other angles of departure, direction of arrival at a flower or inflorescence, were not disfavoured. The model for optimal foraging, as described by Pyke, (1978a) shows that bees forage by going forward alternating between right and left sharp turns, and visiting near neighbours. This pattern keeps foraging insects (bees) on rich patches for a longer period, while reducing the likelihood of revisiting a discrete source of resource (a flower or inflorescence).

Skunk cabbage, Symplocarpus foetidus (L.) Nutt. (Araceae), is one of the earliest blooming plants of the spring in eastern North America. It is reputed to be pollinated by flies (Diptera) which may breed in the inflorescences (Grimaldi \& Jaenike, 1983) and are attracted by the scent, which is variable (Williams, 1919; and below), liberated by the inflorescence (Trelease, 1879; Williams, 1919). The inflorescence generates heat (Knutson, 1972, 1974) which can assist in its growth and maturation as it forces its way through frozen ground, ice, and snow, or may drive off the characteristic scents, attract and protect pollinators, or a combination of the above (Moodie, 1976; Camazine \& Niklas, 1984). The inflorescences are hermaphroditic and strongly protogynous. They require cross-pollination to set fruit (Trelease, 1879; Camazine \& Niklas, 1984). The inflorescences do not produce nectar, and for honey bees (Apis mellifera L.) (Hymenoptera : Apidae) the reward sought is pollen (Quinby, 1865). Doolittle (1900) was of the opinion that skunk cabbage is a valuable source of pollen in early spring, even before the first trees bloom. Trelease (1897), Gibson (1901), and Shufeldt (1919) all remarked on the frequency of honey bees visits and noted that they were often trapped, and died within the spathes. Lovell (1920) noted that large numbers of honey bees collected the pollen of skunk cabbage and became liberally dusted (see also Doolittle, 1900).

The aim of this study was to examine the activity of honey bees on flowering skunk cabbage. The importance of the scent and the colour of the spadix to foraging honey bees is examined together with the influence of the presence of pollen within individual spathes and the degree of reward in various patches of the plants.

\section{MATERIALS AND METHODS}

The study site, near Fonthill, Ontario measured about $0.5 \mathrm{ha}$, within several ha of swampy woodlands having a dense population of skunk cabbage. The plants started to bloom by March 23, 1988 and by April 5, the day of the study, the bloom was at its peak. That particular day was warm (ca. $15^{\circ} \mathrm{C}$ ) and sunny, and honey bees were actively foraging for pollen from the inflorescences.

The inflorescences were surveyed with regard to the presence of pollen within the spathes and their scent. The scents for any one spathe were placed into one of 5 categories : apple, turnip (perhaps the mustard noted by Williams, 1919), garlic (also in Williams, 1919), carrion (also in Williams, 1919), and scentless (by organoleptic testing according to the olfactory appreciation of the four investigators making the study).

As honey bees were observed visiting a particular spathe, they were checked for the presence of pollen loaded in their corbiculae. The spathe was smelt and categorized, together with 
the spathes of the 4 closest neighbouring plants. The visited spathe was checked for the presence of pollen, along with 10 other spathes within a 3-m radius. In the areas where honey bees were not apparent, 10 spathes were also surveyed in a similarly small area. Another batch of spathes were categorized according to scent and the colouration of the spadix (yellowish or with yellowish patches of the stamens or stigmas, and healthy). The result of the surveys were analysed by Chi-squared and Student's $t$ tests.

\section{RESULTS}

The presence of a scent detectable to the human nose appeared to be important in attracting honey bees to a particular spathe. Out of a total of 37 bees, none were observed visiting a spathe without a detectable scent. Scentless spathes comprised $17.6 \%$ of the sample of the closest neighbouring plants ( 5 of these plants had 2 spathes) $(n=153)$ (Chi-squared $=7.9$ for the null hypothesis that the proportion of scented spathes visited by honey bees was the same as that in the general vicinity; $P<0.01$ ). However, the honey bees did not discriminate between the scents as categorized: the honey bees' visits to variously scented spathes were in proportion to their occurrence in the 4 neighbours as follows: apple, 8: 35; turnip, 21: 64; garlic, 6: 24; carrion, 2:3 (Chi-squared $=1.58, P=$ $0.66 ; 27$ spathes were scentless.

To test the hypothesis that the visual cue for pale or pale-spotted spadix was secondary, a survey was made of the colouration and scent of the spadices. The results of the survey were that $80.2 \%$ of the pale or pale-spotted spadices were also scented $(n=167)$. This was not significantly different from the proportion of scented inflorescences ( $82.4 \%$ ) noted above for the general population (Chi-squared $=0.425$; $P \approx 0.5$ ). Only 2 bees, out of 37 observed, (and those were the only ones without pollen loads), entered a spathe without pollen with a dark spadix. In the patches where the honey bees were foraging, there were on average $52.9 \%$ polleniferous inflorescences with pale or pale-spotted spadices $(n=210)$. The probability of observing the above frequency of visitation to pollenfierous blossoms by chance is less than 0.001 by Chi-squared $(=25.7)$ test.

There was a significant difference between the relative numbers of polleniferous inflorescences within patches where honey bees were seen foraging $(52.9 \%, n=210)$, and patches where they were absent at the time of observation $(35.6 \%, n=250)$ (Chi-squared $=12.51, P<0.0014$ ). A more detailed analysis of the frequency distribution of polleniferous inflorescences in the 20 patches with honey bees (the spathe at which the honey bee was seen not being counted), and in 25 patches without honey bees, also indicates a significant difference. The mean proportion of 10 polleniferous inflorescences $( \pm S D)$ in the patches where honey bees were seen was $0.55 \pm$ 0.22 (median $=0.5$ ), whereas, for the other patches, the mean was $0.36 \pm 0.22$ (median $=0.3$ ) (Student's $t=2.95, P=0.005$ ).

\section{DISCUSSION AND CONCLUSIONS}

Honey bees using skunk cabbage as a source of pollen in early spring probably use a variety of sensory cues in order to choose which inflorescences to visit. While foraging among the skunk cabbages, honey bees fly low over the ground (ca. 5-10 $\mathrm{cm}$ ) and investigate shoots and spathes of plants. They choose to visit spathes which emit scents detectable to the human nose 
and not to visit spathes with an undetectable odour. It is generally recognized that honey bees have an olfactory sense which is quite similar, except in the area of their pheromones, to that of humans (von Frisch, 1919, 1967; Butler, 1951; Waddington, 1983); therefore, it can be concluded that the scent, as detected human organolepsy, is a useful cue for the honey bees. They did not discriminate between the different scents of the inflorescences. Instead, they distinguished between inflorescences which proffer pollen, and colouration, of which yellow-spotted spadices appeared to be important. There was not relationship between apparent scentlessness and colouration of the spadix. The 2 honey bees (perhaps newly recruited) which visited inflorescences without pollen and with dark spadices did not carry pollen loads. Their precise activities were not determined. In conclusion, it can be said that honey bees use scent as their first cue to approaching an inflorescence of skunk cabbage, followed by vision and then the colour of the spadix as the cue to the presence of pollen. This behaviour is contrary to the usual order of priority of sensory cues for honey bees foraging at blossoms (von Frisch, 1927; Butler, 1951). How honey bees distinguish, if in fact they can, between inflorescences in female phase and without pollen is unknown.

Particularly interesting is the finding that honey bees were able to distinguish between patches of flowering skunk cabbage which were richer in resources (pollen) than nearby patches in the study area. Their patterns of movement were not followed because there were too few bees and only one opportunity to make observations. The types of flight patterns described by others (Hodges \& Miller, 1981; Zimmerman, 1982a, b; and see introduction) would serve to keep the honey bees on pollen rich patches in a manner consis- tent with optimal (Charnov, 1976), or at least efficient, foraging.

\section{ACKNOWLEDGMENTS}

I am very grateful to my patient and often wetkneed assistants, B. Rathwell, M. Offer, and D. Blades for their help in the field and willingness to subject their noses to the scents of skunk cabbages. I am also grateful to $S$. Meier for kindly reviewing drafts of the manuscript. I thank $P$. Turner for allowing me access to his property for the study. Funding came from the Natural Sciences and Engineering Research Council of Canada (Grant A 8098).

\section{Résumé - La récolte du pollen de Sym-} plocarpus foetidus (Araceae) par l'abeille, Apis mellifica L. Contrairement à la récolte de nectar, l'activité de récolte du pollen a été peu étudiée chez l'abeille. Symplocarpus fœtidus, un arum à très grosses feuilles, est fréquent dans les forêts marécageuses d'Amérique du Nord. II fleurit tôt au printemps et la bractée de l'inflorescence, la spathe, apparait souvent à travers la neige, la glace ou le sol marécageux gelé. Les inflorescences dégagent de la chaleur et des odeurs caractéristiques mimétiques, principalement de charogne mais aussi de pomme, de navet et d'ail. Néanmoins quelques inflorescences n'émettent aucune odeur, au moins durant une partie de leur vie. Elles ne secrètent pas de nectar, sont fortement protogynes (phase femelle en premier) et produisent du pollen en quantité durant leur phase mâle.

Les abeilles visitent les fleurs pour le pollen. Elles ne visitent pas les spathes inodores mais uniquement les odorantes, 
et ce proportionnellement à la fréquence avec laquelle les différentes odeurs se présentent dans un espace donné. Dans une zone de butinage, les abeilles visitent les inflorescences pollinifères avec une fréquence supérieure à celle due au hasard. II n'y a pas de relation entre la présence d'odeur et celle de pollen. Les inflorescences pollinifères ont des spadices de couleur jaunâtre ou présentant des points jaunes dus aux étamines; les spadices plus vieux ou non mûrs sont foncés. Pour choisir les inflorescences à butiner, les abeilles s'orientent à l'odeur d'abord, puis à la vue. Elles butinent dans les zones où les inflorescences pollinifères sont plus nombreuses qu'ailleurs. Pour concentrer leur activité de récolte, elles choisissent donc les inflorescences riches en nourriture (pollen) au sein des zones riches en nourriture.

\section{Apis mellifica - butinage - pollen - Symplocarpus foetidus - Amérique du Nord}

Zusammenfassung - Wie Honigbienen
auf Skunk Cabbage, Symplocarpus fotidus (Araceae), Pollen sammeln. Im Gegensatz zum Nektarsammein wurden die Aktivitäten der Honigbienen beim Pollensammeln noch wenig untersucht. Der Skunk Cabbage ("Skunk-Kohl"), ein Aronstabgewächs mit sehr großen Blättern, ist häufig in sumpfigen Wäldern Nordamerikas zu finden. Er blüht zeitig im Frühjahr und das Hüllblatt des Blütenstandes, die Spatha, bricht oft durch Schnee, Eis und den gefrorenen sumpfigen Waldboden. Die Blütenstände erzeugen Wärme und charakteristische mimetische (nachahmende) Gerüche, vorwiegend von Aas, aber auch von Äpfein, Rüben und Knoblauch. Einige Blüstenstände erzeugen jedoch wenigstens für einen Teil der Blühdauer keinen
Geruch. Die Blütenstände erzeugen keinen Nektar, sind stark protogyn (= zuerst weibliche Phase) und sie produzieren in ihrer männlichen Phase sehr reichlich Pollen.

Honigbienen besuchen die Blüten um Pollen zu sammeln. Sie besuchten duftlose Spathae nicht, sondern sie suchten duftende auf, und zwar in dem Verhältnis, in dem die verschiedenen Düfte in der Trachtfläche vorkamen. Innerhalb der Trachtflächen besuchten die Bienen pollenspendende Blüten häufiger als dies nach einer Zufallsverteilung zu erwarten gewesen wäre. Es war keine Beziehung zwischen dem Vorkommen von Duft und von Pollen festzustellen. Die pollentragenden Blütenstände hatten gelbliche Blütenschäfte oder Blütenschäfte mit gelben Flecken von den Staubgefäßen; ältere und unreife Blütenschäfte hingegen waren dunkel.

Die Bienen orientieren sich zuerst nach dem Duft und dann mit dem Auge, wenn sie die Wahl treffen, bei welchem Blütenstand sie sammeln werden. Die Bienen sammelten auf Flächen, in denen mehr pollenspendende Blütenstände zu finden waren, als in anderen. Die Bienen wählten also ertrag-(pollen-)reiche Blütenstände in ertragreichen Trachtflächen, auf die sie ihre Sammelaktivitäten konzentrierten.

Apis mellifera - Pollensammeln -
Symplocarpus foetidus - Nordamerika

\section{REFERENCES}

Butler C.G. (1951) The importance of perfume in the discovery of food by the worker honey bee (Apis mellifera). Proc. R. Soc. B, 138, 403413 
Camazine S. \& Niklas K.J. (1984) Aerobiology of Symplocarpus foetidus : interactions between the spathe and spadix. Am. J. Bot. 71, 843-850

Charnov E.L. (1976) Optimal foraging and the marginal value theorem. Theor. Popul. Biol. 9, 129-136

Doolittle G.M. (1900) Early pollen and honey. Glean. Bee Cult. 28, 308-309

Frisch K. von (1919) Über den Geruchsinn der Bienen und seine blütenbiologische Bedeutung. Zool. Jahrb. Allg. Zool. Physiol. 37, 1-238

Frisch K. von (1927) Die Sinnesphysiologie der Bienen. Naturwissenschaften 15, 963-968

Frisch K. von (1967) The Dance Language and Orientation of Bees. (Translated by L.F. Chadwick), Belknap Press of Harvard University Press, Cambridge, MA pp. 566

Galen C. \& Plowright R.C. (1985) Contrasting movement patterns of nectar-collecting and pollen-collecting bumblebees (Bombus terricola) on fireweed (Chamaenerion augustifolium) inflorescences. Ecol. Entomol. 10, 9-17

Gibson W.H. (1901) Blossom Hosts Insect Guests: How the Heath Family, the Bluets, the Figworts, the Orchids, and Similar Wild Flowers Welcome the Bee, the Fly, the Moth, and Other Faithful Insects. Newson and Company, New York, pp. 197

Grimaldi D. \& Jaenike J. (1983) The Diptera breeding on skunk cabbage, Symplocarpus foetidus (Araceae). J. N. Y. Entomol. Soc. 91, 83-89

Haynes J. \& Mesler M.R. (1984) Pollen foraging by bumblebees: foraging patterns and efficiency on Lupinus polyphyllus. Oecologia 61, 249-253

Hodges C. \& Miller R.B. (1981) Pollinator flight directionality and the assessment of pollen returns. Oecologia 50, 376-379

Knutson R.M. (1972) Temperature measurements of the spadix of Symplocarpus foetidus (L.) Nutt. Am. Midl. Nat. 88, 251-254
Knutson R.M. (1974) Heat production and temperature regulation in eastern skunk cabbage. Science (Wash.) 186, 746-747

Lovell J.H. (1920) The Flower and the Bee: Plant Life and Pollination. Constable and Co. Ltd., London, pp. 286

Moodie G.E.E. (1976) Heat production and pollination in Araceae. Can. J. Bot. 54, 545-546

Pyke G.H. (1978a) Optimal foraging movement patterns of bumblebees between inflorescences. Theor. Popul. Biol. 13, 72-98

Pyke G.H. (1978b) Optimal foraging in bumblebees and coevolution with their plants. Oecologia 36, 281-293

Pyke G.H. (1979) Optimal foraging in bumblebees : rules of movement between flowers within inflorescences. Anim. Behav. 27, 1167-1181

Quinby M. (1865-1866) The Mysteries of Beekeeping Explained (containing the result of thirty-five years experience, and directions for using the movable comb and boxhive, together with the most approved methods of propagating the Italian bee). Orange Judd and Co., New York, pp. 348

Shufeldb R.W. (1918) The much-despised skunk-cabbage - earliest of spring flowers. Am. For. 24, 225-231

Trelease W. (1879) On the fertilization of Symplocarpus foetidus. Am. Nat. 13, 580-581

Waddington K.D. (1983) Foraging behavior of pollinators. In : Pollination Biology (L. Real, ed.), Academic Press, Orlando, Florida, Chapter 9, pp. 213-239

Williams K.A. (1919) A botanical study of skunk cabbage, Symplocarpus foetidus. Torreya, 19, 21-26

Zimmerman M. (1982a) The effect of nectar production on neighbourhood size. Oecologia, 52, 104-108

Zimmerman M. (1982b) Optimal foraging : random movement by pollen collecting bumblebees. Oecologia 53, 394-398 